\title{
Herman Wedel Major - personen, legen og reformatoren
}

\begin{abstract}
Herman Wedel Major har satt varige spor i norsk medisinsk historie med sine omfattende reformer for mennesker med psykiske lidelser. Han sto bak utformingen av vår første særlov som regulerte psykisk helsevern i Norge i 1848, og etableringen av Gaustad Asyl, landets første statsasyl i 1855.
\end{abstract}

Han var påsatt til å tiltre stillingen som direktør ved Gaustad og flyttet inn i direktørboligen to år før sykehuset åpnet, men trakk seg overraskende fra stillingen et drøyt år før de første pasientene ble tatt imot. I stedet emigrerte han til Amerika, men omkom med nær familie under reisen da skipet forliste.

I ettertiden har det oppstått motstridende beskrivelser av Majors personlighet og egenskaper. Jeg tar i denne artikkelen opp noen milepæler ved hans liv og virke.

«Du ved hvor vanskelig jeg kan forstaaes til bunnen, du ved der gives et elskovsdyb $i$ min sjel hvori mange af mine store feil og mangler kunde druknes»

Herman Wedel Major i brev til sin yndlingssøster Mimi, 1842

I mai 1798 fløt det en sukkertønne i land i Kristiansand. Tønnen inneholdt ikke sukker, men frihetskjemperen og opprøreren Robert Gonsalvo Major (1766-1839) fra Belfast. Han var en av lederne i «United Irishmen», en forløper for IRA. Etter et mislykket opprør mot engelskmennene måtte han rømme fra Irland i all hast, en flukt som endte i Kristiansands havn.

Det finnes andre og mer sannsynlige historier om hvordan Robert Major kom til Norge. Sikkert er det imidlertid at han ankom Kristiansand selvsamme mai i 1798, uten annet enn det han gikk og sto i. Tilbake i Irland hadde han kone og to barn. I Norge slo han seg raskt opp på handel og giftet seg på nytt i 1802 med Sophie Benedicte Weideman (1783-1859). De fikk ni barn. Det syvende i rekken var Herman Wedel Major (1814-54).

Herman Wedel Major blir med rette husket i norsk medisinsk og sosialpolitisk historie som den som reformerte sinnssykeomsorgen i Norge. I november 2014 arrangerte Norsk psykiatrisk forening et «Majorseminar» for å minnes Major 200 år etter hans fødsel. Denne artikkelen er en bearbeidet versjon av et innlegg undertegnede holdt på dette seminaret. I det følgende menes med «Major» Herman Wedel Major, mens andre i familien omtales med for- og etternavn.

\section{Mennesket}

Fra barndommen er det sparsomme opplysninger om Major. Forholdet mellom foreldrene var vanskelig, og de ble skilt i 1820. Like fullt ble Majors yndlingssøster Sophia Ottilia Major - kalt Mimi - født året etter skilsmissen. Mimi giftet seg senere med arkitekten Heinrich Ernst Schirmer (1814-87), som ble en viktig medarbeider for Major i arbeidet med å realisere Norges første statsasyl - Gaustad.

Major vokste opp i Kristiansand, men flyttet til øvre Ullern gård før avsluttet skolegang. Han trivdes dårlig på skolen. 17 år gammel sluttet han, men gjennomførte senere artium som privatist med karakteren «Non». («Non» står for «ikke å forakte», og var den siste karakteren før strykkarakteren «Imaturus»). Han ble immatrikulert ved Universitetet i Oslo i 1832, der han et år senere avla examen philosophicum med dårlig karakter. Major begynte deretter på medisinstudiet, hvor han trivdes bedre, og i 1842 avla han embetseksamen som beste kandidat på kullet.

Majors far tok sitt eget liv i 1839. Henrik Wergeland, som var blitt en venn av familien Major, skrev diktet Robert Major etter hans død. Wergeland og Major begynte samtidig på medisinstudiet og ble nære venner. Wergeland hadde tidligere skrevet diktet Spanjolen (1833) som han dedikerte til Robert Major. Utover den personlige tragedien farens selvmord representerte, fikk hendelsen betydning for hvordan ettertiden vurderte Majors psykiske helse. Så vel Paul Winge (1) som senere Johan Scharffenberg (2) mer enn antyder at Robert Major led av hva som i dag ville blitt diagnostisert som bipolar lidelse, og at Major var arvelig belastet. De hevdet at Major særlig i de senere årene av sitt virke i tiltagende grad var plaget med endogene depresjoner med enkelte hypomane perioder, og at denne lidelsen var en vesentlig årsak til at Major trakk seg fra stillingen som direktør ved

\author{
Georg Høyer \\ georg.hoyer@uit.no \\ Institutt for samfunnsmedisin \\ Universitetet i Troms $\varnothing$ - \\ Norges arktiske universitet
}

> Se også side 1060

\section{HOVEDBUDSKAP}

Den norske legen og psykiateren Herman Wedel Major regnes som hovedmannen bak sinnssykeloven av 1848 - den første særloven som regulerte psykisk helsevern i Norge

Major ledet planleggingen av Gaustad Asyl, landets første statsasyl, som ble etablert i 1855 
Gaustad. Basert på slektshistorie og private brev utfordrer imidlertid Randi Haukeland, som var oldebarn av Majors yndlingssøster Mimi, påstandene om at Major led av en sinnslidelse (3).

I 1840 forlovet Major seg med niesen Fanny Rahbek. Fanny var datter av Majors eldre søster Nahyda, gift med den daværende danske generalkonsulen Otto Rahbek. Fanny hadde, da forlovelsen ble inngått, hatt tegn på alvorlige psykiske lidelser («raseri»), og da Fanny på nytt fikk alvorlige anfall, måtte Nahyda og Major i 1842 følge Fanny til Schleswig der hun ble innlagt på et, etter datiden moderne asyl ledet av professor Peter Willers Jessen (17931875). Fanny var innlagt fra 1842 til 1845. Forlovelsen ble hevet i 1842, men Major bevarte i mange år håpet om at Fanny skulle bli helbredet. Dette skjedde imidlertid ikke. Fanny ble overflyttet fra Schleswig til et asyl i Danmark og senere innlagt på Gaustad i 1859. Major ga etter hvert opp håpet om gjenforening med Fanny og giftet seg i 1850 med Ida Cathrine Grünning (182154). De fikk to døtre, Emma og Ida.

Major var utpekt til stillingen som direktør ved Gaustad Asyl og flyttet inn i direktørboligen to år før sykehuset ble åpnet 1. oktober 1855. Han trakk seg som nevnt fra stillingen og emigrerte til USA høsten 1854. Skipet de reiste med, kolliderte og sank før de nådde USA, og alle i familien Majors følge druknet.

\section{Reformatoren}

Major hadde vist interesse for psykiatri allerede i studietiden, men Fannys sykdom ble avgjørende for at han valgte å engasjere seg i arbeidet med å reformere sinnssykeomsorgen i Norge. På den tiden da Fanny ble syk, fantes ingen andre psykiatriske institusjoner enn dollhusene, der forholdene var elendige. I 1822 beskrev Frederik Holst (1791-1871) tilstanden ved Oslo Hospitals dollhus som verre enn «dem man tilbød de usleste husdyr» (4). Lite hadde endret seg til det bedre i 1840-årene, og der familiene hadde midler, ble familiemedlemmer som utviklet alvorlige sinnslidelser, lagt inn ved institusjoner i utlandet.

I perioden 1842-1846 gjennomførte Major omfattende studiereiser i Tyskland, Belgia, England og Frankrike. Særlig mye tid tilbragte han hos Jessen, og institusjonen i Schleswig ble brukt som modell da planene for Gaustad ble utformet. Jessen bidro selv med innspill og råd i Majors arbeid for et nytt asyl i Norge. I 1844 kunne Major legge frem Utkast til et nytt sinnsykeasyl $i$ Norge med tegninger (5). Tegningen var utarbeidet av svogeren Schirmer som på den tiden allerede hadde gjort seg bemerket, blant annet som arkitekt for botsfengselet (åpnet 1845) og Nasjonalgalleriet, og med restaureringen av Nidarosdomen (6). Selv om planene for et nytt asyl ble godt mottatt, gjorde den økonomiske situasjonen at det gikk enda 11 år før planen lot seg realisere og Gaustad ble åpnet.

I tiden fra 1845 til 1848 konsentrerte Major seg om arbeidet med også å få lovregulert sinnssykepleien. Han var inspirert av Philippe Pinels (1745-1826) elev, JeanÉtienne Dominique Esquirol (1772-1840). Mens Pinel i psykiatriens historie fremstår som den store reformatoren av omsorgen for sinnslidende, basert på medisinske $\mathrm{og}$ humanistiske prinsipper, la Esquirol avgjørende vekt på at reformer innen sinnssykepleien måtte støttes av lovgivning for å hindre at omsorgen falt tilbake i gamle folder. Jessen spilte som nevnt en viktig rolle i Majors reformarbeid fordi han allerede hadde realisert prinsippene til Esquirol i Schleswig. Prinsippene til Esquirol var, i tillegg til vektlegging av lovregulering, i stor grad en videreføring av Pinels anbefalinger: en nøye klassifikasjon av pasientene etter diagnose, funksjonsnivå og prognose. Pasienter av samme klasse og kjønn skulle plasseres på samme avdeling og helst ikke omgås andre pasienter. De nye asylene skulle kun ta imot sinnslidende, og de skulle ligge isolert til i vakre omgivelser. Pasientene skulle ha ro og være omgitt av et vennlig og omsorgsfullt personale under gode materielle forhold.

Det oppsto likevel et viktig skille mellom reforminitiativene innen sinnssykeomsorgen som ble fremmet tidlig på 1800-tallet, og Majors initiativ. Pinels reform var først og fremst en humanistisk reform og kom som en reaksjon på de nedverdigende og uakseptable måtene sinnslidende ble behandlet på. Samtidig understreket Pinel at det dreide seg om sykdommer, og at «de gale» måtte skilles ut fra andre grupper som var sperret inne på allmennhospitalene, slik som psykisk utviklingshemmende, fysisk funksjonshemmede, fattige og kriminelle. Hovedsynet i tiden umiddelbart etter at Pinel publiserte sitt hovedverk, også kalt den første læreboken i psykiatri (7), var at man måtte skille mellom helbredelige og uhelbredelige sinnslidelser.

I tråd med Pinels syn foreslo Frederik Holst i sitt reformforslag for sinnssykeomsorgen fra 1828 at det skulle bygges atskilte institusjoner for sinnssyke: fire St. Johannes-stiftelser for de helbredelige og syv St. Emanuels-institusjoner for de uhelbredelige. Knapt 20 år senere hevdet Major at alle kunne helbredes:

«Den første Grundvold baade for forbedringerne af de Sindsyges Forholde, og for Lægevidenskabens Fremadskriden er at Staten erkjendte denne del af sine Medlem- mer ikke blot for Syge, ....men også for Helbredelige, der kun ved Ligegyldighet, Forsømmelse eller virkelig Mishandling saa ofte nedsynke eller nedstedes i hjælpeløs Elendighet og livsvarig Jammer.» (5)

På bakgrunn av de erfaringene han hadde høstet, var det maktpåliggende for Major at det ble etablert nye asyl basert på nye ideer om sinnslidendes behandling og prognose. Hans viktigste punkter i dette reformarbeidet var at de eksisterende institusjonene dollhusene - ikke måtte rehabiliteres, men nedlegges, at staten, og ikke fattigvesenet, skulle ha ansvar for de nye asylene og at sinnssykeomsorgen måtte reguleres i særlov.

Norge ble det sjette land i Europa som fikk på plass en særlov for sinnssykeomsorgen. Da lov om sinnssykes behandling og forpleining ble vedtatt 17 . august 1848 , ble ikke - til Majors store skuffelse - dollhusene nedlagt i forbindelse med reformen. Ei heller ble fattigvesenet helt fratatt sin rolle i sinnssykeomsorgen. Majors skuffelse på disse punktene er senere fremholdt som en mulig grunn til at han trakk seg fra direktørstillingen på Gaustad.

Sinnssykeloven av 1848 viste seg å være særdeles levedyktig - den var i kraft til 1961. Endringene som ble vedtatt senere, var små og uvesentlige, med unntak av at det ble åpnet for frivillige innleggelser i 1935.

\section{Legen}

Helt fra medisinstudiet, men også parallelt med sitt reformarbeid og senere legegjerning, var Major opptatt av kjemi. Han manuduserte ved kjemisk institutt parallelt med medisinstudiene, og så sent som i 1854 publiserte Major en artikkel om salpetersyrens innvirkning på salicin, en artikkel som vakte internasjonal oppmerksomhet (8). Det er senere spekulert i at Majors kjemiske arbeid fra 1854 tydet på at han i det stille planla å skifte felt fra psykiatri til kjemi, og at dette skulle realiseres i USA.

Major hadde ikke noen direkte klinisk erfaring med behandlingen av sinnslidende før han fikk stilling som lege, senere overlege, ved Oslo Hospital i 1847, en stilling han hadde helt til han emigrerte til Amerika. Mens byggearbeidene på Gaustad pågikk foreslo Major for Paul Winge, som var overlege ved Christiana bys dollhus (Mangelsgården), at de sammen skulle etablere et privat asyl, men Winge avslo. Også dette har vært trukket frem som et tegn på at Major var usikker på en fremtid som direktør ved Gaustad.

Major var forankret i den somatiske retningen innen psykiatrien, som i korthet gikk ut på at alle psykiske lidelser hadde sin rot i somatiske lidelser, enten i hjernen eller 
andre organer, og at behandlingen tilsvarende måtte være fysisk. Han har selv beskrevet en rekke kasuistikker og behandlingsmåter han benyttet i sitt virke ved Oslo Hospital (9). Han benyttet medikamenter som kloroform, morfin, opium, kinin, digitalis, vismut, sink og boraks, i tillegg til fysiske behandlingsformer som klyster, blodigler, varme og kalde bad, prolongerte bad og nedkjøling av hjernen ved å overrisle hodet med kaldt vann. Hans somatiske ståsted kommer klart frem når han uttaler følgende om delirium som symptom:

«Men glemmer man, at det (deliriet) altid, saavel i den acute som chroniske Form, kun er et Symptom af en organisk Lidelse, da forlader man den naturvidenskabelige Granskning og henledes til philosophiske Speculationer, som aldrig i nogen Deel af Medicinen have fõrt eller kunne fõre til virkelige Fremskridt.» (9)

Et slikt syn sto i tydelig kontrast til det psykiske eller metafysiske prinsipp, som bygde på den gryende psykologiske vitenskapen, inspirert av Kant og Hume. En tredje retning som vant mange tilhengere på begynnelsen og midten av 1800-tallet, var «moral treatment» som i mindre grad var opptatt av årsaker til sinnslidelser, men i stedet bygde på en slags miljøterapeutisk tilnærming med sterk vekt på en human behandling av pasientene, der tvang ikke hadde noen plass. «Moral treatment» ble særlig utbredt i England, USA, Belgia, Nederland og Tyskland, men fikk liten eller ingen innflytelse i norsk psykiatri.

\section{Gåten Major}

Det gjenstår mange ubesvarte spørsmål om Major og hans liv. Disse spørsmålene dreier seg vesentlig om Major var et friskt og skuffet eller et psykisk sykt menneske som etter hvert var uegnet for legeyrket. Var han usikker på egne evner og krefter?
Eller var han bevisst og målrettet $i$ arbeidet med å reformere psykiatrien? Var han et romantisk og ustadig følelsesmenneske, eller en rasjonell, men empatisk person?

Beskrivelsene av Majors personlighet i eksisterende kilder er motstridende, og det er mulig å finne holdepunkter for ulike syn på hans væremåte og funksjon. Debatten om hvorfor han ikke tiltrådte stillingen som direktør ved Gaustad Asyl, og i stedet valgte å emigrere til USA, er preget av slike ulike oppfatninger av hans sinnstilstand. Han var selvskrevet til denne stillingen, og så sent som i oktober 1853 flyttet han inn i direktørboligen med sin familie. Men allerede 10. januar 1854 sendte han sin avskjedssøknad. Den ble ikke innvilget. Han fikk imidlertid permisjon til å reise til USA, der han oppholdt seg fra mars til juli i 1854. Da han kom tilbake til Norge, søkte han på ny avskjed fra direktørstillingen, og denne gangen ble søknaden innvilget. Da Paul Winge avslo å søke stillingen som ny direktør ved Gaustad, etter at han var blitt oppfordret av Major om å søke, anbefalte Major i stedet Ole Rømer Sandberg til denne stillingen. Sandberg takket ja og ble den første direktøren på Gaustad da asylet åpnet 1. oktober 1855 .

Major og hans familie gikk i stedet om bord i hjuldamperen Arctic 20. september 1854. Alle i familien Majors følge omkom da Arctic kolliderte med et annet skip og sank. De få av de øvrige passasjerene som overlevde, kunne fortelle at Major var rolig og besluttsom da den fatale kollisjonen fant sted, og at han gjorde en forbilledlig innsats med å prøve å redde andre som var om bord (3).

Sett i lys av Majors enestående innsats med å reformere norsk psykiatri, er det til nå bare publisert bruddstykker fra et livsverk som har betydd så mye for omsorgen for psykisk syke i Norge. Scharffenberg planla i sin tid å skrive Majors biografi, og han samlet systematisk materiale til et slikt verk. La oss håpe at noen fullfører Scharffenbergs prosjekt.

Personen, legen og reformatoren Major fortjener å bli husket for sin innsats.

\section{Georg Høyer (f. 1947)}

er professor, leder av Nettverket for forskning og kunnskapsutvikling om bruk av tvang i det psykiske helsevernet og leder av medisinsk gruppe i Den europeiske komité for forebygging av tortur og umenneskelig eller nedverdigende behandling eller straff (CPT).

Forfatter har fylt ut ICMJE-skjemaet og oppgir ingen interessekonflikter.

\section{Litteratur}

1. Winge P. Mindetale over Herman Major. Norsk Magasin for Lægevidenskab 1914; 75: 562-73.

2. Scharffenberg J. Herman Major. Tidsskr Nor Lægeforen 1914; 34: 201-11.

3. Haukeland R. Herman Wedel Major i Johan Scharffenbergs bilde. En kritisk revurdering. Tidsskr Nor Lægeforen 1993; 113: 3703-8.

4. Holst F. Beretning om Oslo Dollhuses nuværende Tilstand, samt Wink til sammes hensigtsmæssigere Indretning og Forslag til Oprettelsen af en ny Helbredelsesanstalt for Sindssvage. Budstikken 1822; 3: 595-624

5. Major HW. Forslag til Sindssyge-Asyl for Norge. Ugeskrift for Medicin og Pharmacie 1845; 4: 49-74.

6. Hvattum M. Heinrich Ernst Schirmer. Kosmopolittenes arkitekt. Oslo: Pax Forlag, 2014.

7. Pinel P. A treatise on insanity. London: Messers Cadell \& Davies, Strand, 1806

8. Hjortdal T. Et kemisk arbeide av den norske læge Herman Major. Tidsskrift for kemi, farmaci og terapi 1914; 8: 113-116

9. Major HW. Oversigt over Oslo Sindssyge-Afdelings Virksomhet i Tidsrummet 1847 til 1852. Norsk Magasin for Lægevidenskap 1854; 8: 27-59.

Mottatt 2.9.2015, første revisjon innsendt 4.5.2016, godkjent 6.5.2016. Redaktør: Ketil Slagstad. 